\title{
Satellite-derived sea surface temperature from Caribbean and Atlantic coral reef sites, 1984-2003
}

\author{
R.L. Hayes ${ }^{1,2}$ \& T.J. Goreau ${ }^{2}$ \\ 1. College of Medicine, Howard University, Washington, DC 20059; USA; rhayes@howard.edu \\ 2. Global Coral Reef Alliance (GCRA), 37 Pleasant St., Cambridge, MA 02139 USA; goreau@bestweb.net
}

Received 10-VI-2007. C Corrected 15-XII-2007. Accepted 13-II-2008.

\begin{abstract}
A database of monthly average sea surface temperature (SST) from 1984-2003 has been developed from U.S. National Oceanic and Atmospheric Administration (NOAA) Polar Operational Environmental Satellite (POES) Advanced Very High Resolution Radiometer (AVHRR) records, corresponding to geographic coordinates for 51 reef tracts throughout the Caribbean Sea and Atlantic Ocean. These data represent part of a collective SST record for 206 globally-distributed coral reef sites in the Global Coral Reef Alliance (GCRA) Coral Reef SST Database (www.globalcoral.org). The temperature series covers two full decades of active climate change and marine ecosystem responses, during which mass coral reef bleaching, emerging diseases, biodiversity losses, species mortalities, fisheries declines, and reef frame degradation have been reported. Reef ecosystem changes appear when the monthly SST anomaly exceeds $1.0^{\circ} \mathrm{C}$ above warm season averages, defined as a Hot Spot. If the anomaly reaches $2^{\circ} \mathrm{C}$ or more and/or if the duration of the anomaly is prolonged at the same site, the ecological responses are more severe. Linear trend lines and regression coefficients for the SST at each site document both the degree and rate of temperature change, allowing comparisons to be made among sites. Impacts from coastal upwelling that circulates deep, cool and nutrient-rich water to the surface and alters the productivity of reef fisheries are embedded within the SST record. Maximum and minimum temperature exposures, yearly variations in SST, and seasonal fluctuations may be analyzed from the database. These calibrated and comparative data serve to describe how SST trends at a site contrast or conform to neighboring upstream or downstream sites. Site-specific thermal records offer a basis for developing individualized management strategies and for formulating unique conservation policies for regional reefs. The differences among temperature trends in the database may account for the degradation of some reefs and the relative sparing of others. From this historical record of thermal conditions on coral reefs, we may generate early alerts about potential marine ecosystem responses from persistent climate change. Rev. Biol. Trop. 56 (Suppl. 1): 97-118. Epub 2008 May 30.
\end{abstract}

Key words: sea surface temperature, coral reef bleaching; Caribbean/Atlantic.

Recent studies of ocean temperature, salinity and $\mathrm{pH}$ clearly indicate that the world's seas are changing (Curry et al. 2003, Caldeira and Wickett 2003, 2005, Levitus et al. 2005, Boyer et al. 2005). Among these changes, gradual warming extends from the surface down to the deepest depths of the ocean (Barnett et al. 2005). Surface warming of the oceans is attributable to direct heat transfer from the atmosphere in response to global climate change over recent decades (Hansen et al. 2005). In spite of the fact that such thermal aberrations are now confirmed, details of regional trends in sea surface temperature (SST) are not readily available.

In this study, we have constructed monthly average satellite-derived SST data for coral reef sites in Caribbean and Atlantic regions. We hypothesize that with these data, we shall be better prepared to understand, if not to predict, the ocean temperature changes that are postulated to have triggered responses in marine ecosystems, as has been documented in terrestrial ecosystems (Parmesan \& Yohe 2003). Mass coral reef bleaching, the uncoupling of symbiotic associations in reef communities, is 
now generally accepted by marine scientists as a thermal stress response (Glynn 1993, Goreau \& Hayes 1994). Organisms in these tropical marine ecosystems live close to their upper tolerance limit for temperature. During the warmest season of the year, even minor increases in temperature for prolonged times can be stressful and disruptive. Consequently, even in areas of the global tropics with no observers and no documentation, the SST record should suggest conditions favoring a bleaching stress response. From the historical SST record, we can describe and evaluate the thermal exposures of various reef communities. From this understanding of the environmental conditions to which coral reefs have been exposed, we should be better able to determine how changes in temperature might have contributed to the expression of bleaching stress responses in coral reef ecosystems. Furthermore, this understanding should allow us to anticipate or predict conditions which are most likely to produce future episodes of regional coral bleaching.

In this report, a set of 51 reef sites from within the Caribbean Sea and adjacent North and South Atlantic Ocean has been examined as a demonstration of the power of this SST database. Monthly average proxy values for these offshore reef sites were assembled from 20 years of U.S. National Oceanic and Atmospheric Administration (NOAA) Polar Operational Environmental Satellite (POES) Advance Very High Resolution Radiometer (AVHRR) data. These data represent a minor fraction of the globally distributed survey of 206 sites. The collective series of values has been designated the Coral Reef SST Database. The full data set is available on the Global Coral Reef Alliance (GCRA) website [www. globalcoral.org] for access by marine scientific researchers upon request.

SST trends may be examined individually for each reef site as annual or multi-annual records. Also, neighboring sites may be compared and records from multiple sites may be contrasted. The full range of thermal exposure for a site may be determined by looking at the maximum and minimum values in the database for that site over the duration of the study period (1984-2003). A record of linear trend lines was generated for each site, allowing comparisons of linear formulae and regression coefficients for each site. Observations from reef sites examined by researchers allow these SST data to be placed in context, before, during and after ecological responses were reported. Based upon the annual changes in SST exposure, regional changes in surface water heat flow are evident. An awareness of surface current dynamics in near-shore and shallow water areas is most important for tracking the emergence, expansion, re-location, and ultimate dissipation of any SST Hot Spot (a sustained SST anomaly of $+1.0^{\circ} \mathrm{C}$ or more) influencing a coastal marine ecosystem.

\section{MATERIALS AND METHODS}

NOAA POES AVHRR climate data (Reynolds \& Marisco 1993, Reynolds and Smith 1994, Strong et al. 2000, Reynolds et al. 2002, Climate Diagnostics Bulletin, NOAA 1982-2003) have been used to generate monthly average SST records for 206 coral reef tracts throughout the world from 1982-2003. These are assembled into the GCRA Coral Reef SST Database. The monthly NOAA Climate Diagnostics Bulletin fields are derived by linear interpolation of weekly fields to daily fields that are then averaged over a month on a one degree grid. Satellite data are adjusted for biases using the method of Reynolds (1988) and Reynolds and Marisco (1993). Included among these records are SST data from 51 reef sites in the Caribbean Sea and the adjacent North and South Atlantic Ocean. These regional data document a 20-year history of climate conditions that coincide in time and correlate in space with reports of reef ecosystem responses to recent global warming and extreme climate change.

Selected analyses of the data from these fifty-one sites were prepared to illustrate the application of the data in the GCRA series. Data from the US Virgin Islands were used to illustrate both the full data set (1982-2003) and a series from which years of volcanic eruptions 
(1982 and 1991) and years of El Niño Southern Oscillation (ENSO) events (1983, 1987, 1992 and 1998) were removed. Also, we tabulated the highest and lowest monthly temperatures for each site over time in order to evaluate the ranges of thermal exposures to which each reef has been exposed. The duration and frequency of these extremes is available in the individual site records. Finally, we have juxtaposed paired sites sharing common longitudes or common latitudes. This has allowed comparisons to be made among these sites, depicting differential thermal patterns within the four quadrants of the Caribbean basin.

Tables 1 and 2 contain lists of the reef sites surveyed and indicate the proxy geographic coordinates for these reef sites. The respective longitudes and latitudes were chosen to represent average or typical values for each site and to assure that only offshore temperatures were recorded with no contamination from terrestrial sources. As such, the data do not represent back reef or lagoon areas, but would best correspond to the fore reef slope zone within a fringing or barrier reef complex. The back reef SST would generally be expected to be slightly higher and to persist longer than the offshore SST, due to weaker flow rates and reduced wind velocities, except for sites with thermal influences of surface and groundwater discharges from land.

For each site, monthly average SST data were recorded from 1984-2003. Several years can be uniquely identified in the record because of the higher temperature impacts of ENSO conditions (Soden 2000) and because of the lower temperature impacts due to the emission of atmospheric aerosols from volcanic eruptions (Andreae et al. 2005). We did not remove years during which La Niña conditions prevailed. Other years may be similarly identified because of sites in the track of extreme weather events (e.g., hurricanes), although we did not attempt to do so in this study (Emanuel 1987, 2005, Webster et al. 2005). We present the reduced data set from St. Thomas/St. John from which each of those years has been removed (Fig. 3). In figures 5-11, we present the reduced SST monthly data for the other 51 sites covered by this study.
Comparative presentations of annual records and contrasting data from sites sharing either similar latitudes or similar longitudes illustrate the type of information that may be extracted from the data. In figures 13 and 14, summaries of the regional pairs are presented. The Caribbean map (Map in next page) shows the approximate location of those sites analyzed in figures 13 and 14 and the respective subdivisions of the region that they represent. These observations could not have been appreciated without juxta-positioning comparable SST data from these sites in graphic format (Tables 1, 2).

\section{RESULTS}

Graphic displays of each site record were produced and trend lines were constructed for each. The results of the trend analysis are shown as linear formulae and regression coefficients in Table 3. Selected graphics from St. Thomas/St. John, USVI are presented to illustrate the site-specific SST data (Figs. 1-4).

Each of the Caribbean coral reef sites reveals a seasonal configuration of winter low temperatures and summer high temperatures (Fig. 1). The range between low and high, as

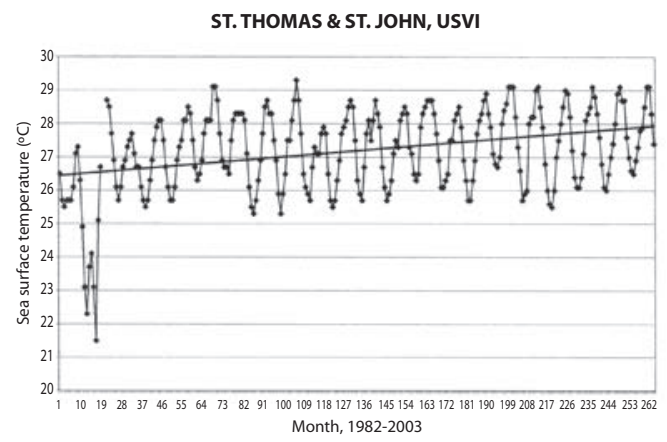

Fig. 1. Graphic display of monthly average SST data for proxy coordinates of St. Thomas and St. John, United States Virgin Islands, 1982-2003. Months \#1-12 represent 1982; \#13-24, 1983; \#25-36, 1984; \#37-48, 1985; etc. A linear regression trend line is drawn through the data. From these data, site-specific records may be compared. The record indicates a net linear increase in SST at this site over the full 22-year period. That increase was $1.5^{\circ} \mathrm{C}$ from 26.5 to $28^{\circ} \mathrm{C}$. Compare these graphic data to the reduced data set in Figure 3. 


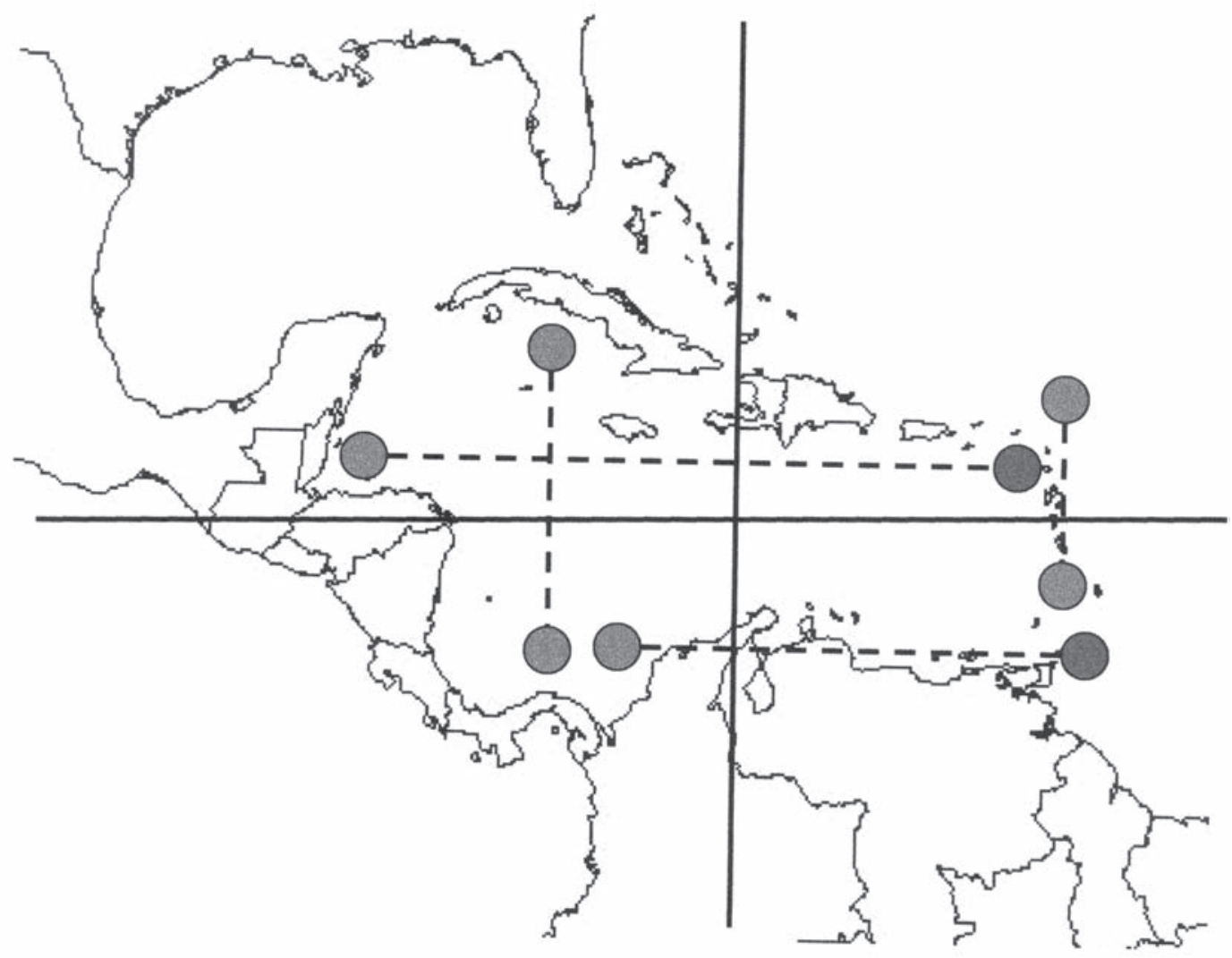

Map. Schematic of the Caribbean basin indicating the relative locations of the paired coral reef sites from Figs. 13 and 14. Sites marked by grey dots in the NE are Antigua and St. Kitts/Nevis; sites in the SE are Grenada and Trinidad/Tobago; sites in the NW are Santa Clara, Cuba and Belize (Glover's); sites in the SW are Portobelo, Panama and Cartagena, Colombia. Although not plotted on this map, our complete Caribbean database includes 8 sites in the NE quadrant, 14 in the NW quadrant, 9 in the SE quadrant and 5 in the SW quadrant, as indicated in Table 1.

shown for St. Thomas/St. John is approximately $3.0^{\circ} \mathrm{C}$. The high temperatures at this site were $28-29^{\circ} \mathrm{C}$, except in 1987 and 1990 . However, from 1998 through 2003, each annual high temperature reached $29^{\circ} \mathrm{C}$. The linear trend line for this site shows a positive slope, indicating that warming was increasing during the series observed.

Average monthly temperatures for St. Thomas/St. John are different for different years (Fig. 2). With the exception of January (month \#1), all other monthly averages in 2003 exceeded the same month of 1984 . Net monthly temperature elevations in 2003 ranged from $0.4{ }^{\circ} \mathrm{C}$ (in February, month \#2) to nearly $2.0^{\circ} \mathrm{C}$ (October, month \#10) above 1984 values. During the three months of August through October, reefs were exposed to temperatures in excess of $29^{\circ} \mathrm{C}$. In those months, temperatures averaged $1.5^{\circ} \mathrm{C}$ degrees above the 1984 level. In 1998, an El Niño year, SST elevations began in May and were sustained through the balance of the year, although September through December values did not exceed values during comparable months in 2003. Although not done for this study, averages of several years running may also be developed for comparative analyses of SST trends (e.g., 1984-1986 versus 2001-2003).

When removing years of volcanic activity and El Niño effects, the trend still shows a 
TABLE 1

Caribbean reef sites in the GCRA database with proxy coordinates for longitudes and latitudes $(N=36)$

\section{CARIBBEAN REEF SITES (N=36)}

\begin{tabular}{|c|c|c|c|}
\hline REEF SITE & LOCATION & LONGITUDE & LATITUDE \\
\hline ANGUILLA & NE CARIBBEAN & $63.1^{\circ} \mathrm{W}$ & $18.3^{\circ} \mathrm{N}$ \\
\hline ANTIGUA & NE CARIBBEAN & $62{ }^{\circ} \mathrm{W}$ & $17^{\circ} \mathrm{N}$ \\
\hline ARUBA & SE CARIBBEAN & $70^{\circ} \mathrm{W}$ & $12.3^{\circ} \mathrm{N}$ \\
\hline BARBADOS & SE CARIBBEAN & $59.7^{\circ} \mathrm{W}$ & $13.2^{\circ} \mathrm{N}$ \\
\hline BARBUDA & NE CARIBBEAN & $62^{\circ} \mathrm{W}$ & $17.7^{\circ} \mathrm{N}$ \\
\hline BELIZE - NORTH & NW CARIBBEAN & $87.9^{\circ} \mathrm{W}$ & $17.8^{\circ} \mathrm{N}$ \\
\hline BELIZE -GLOVER'S & NW CARIBBEAN & $88^{\circ} \mathrm{W}$ & $17.4^{\circ} \mathrm{N}$ \\
\hline BELIZE - SOUTH & NW CARIBBEAN & $88.3^{\circ} \mathrm{W}$ & $16.1^{\circ} \mathrm{N}$ \\
\hline BOCAS DEL TORO & SW CARIBBEAN & $82^{\circ} \mathrm{W}$ & $9.5^{\circ} \mathrm{N}$ \\
\hline BONAIRE & SE CARIBBEAN & $68.4^{\circ} \mathrm{W}$ & $12.1^{\circ} \mathrm{N}$ \\
\hline CARTAGENA & SW CARIBBEAN & $75.5^{\circ} \mathrm{W}$ & $11^{\circ} \mathrm{N}$ \\
\hline CAYO LARGO & NW CARIBBEAN & $81.5^{\circ} \mathrm{W}$ & $21.5^{\circ} \mathrm{N}$ \\
\hline CHINCHORRO & NW CARIBBEAN & $87.5^{\circ} \mathrm{W}$ & $18.5^{\circ} \mathrm{N}$ \\
\hline COZUMEL & NW CARIBBEAN & $85.7^{\circ} \mathrm{W}$ & $20.6^{\circ} \mathrm{N}$ \\
\hline CURAÇAO & SE CARIBBEAN & $68.9^{\circ} \mathrm{W}$ & $12.1^{\circ} \mathrm{N}$ \\
\hline GRAND CAYMAN & NW CARIBBEAN & $81.29^{\circ} \mathrm{W}$ & $19.4^{\circ} \mathrm{N}$ \\
\hline GRENADA & SE CARIBBEAN & $62^{\circ} \mathrm{W}$ & $12^{\circ} \mathrm{N}$ \\
\hline HAITI & NE CARIBBEAN & $73^{\circ} \mathrm{W}$ & $20^{\circ} \mathrm{N}$ \\
\hline DISCOVERY BAY & NW CARIBBEAN & $73^{\circ} \mathrm{W}$ & $18.5^{\circ} \mathrm{N}$ \\
\hline NEGRIL & NW CARIBBEAN & $78.5^{\circ} \mathrm{W}$ & $18.3^{\circ} \mathrm{N}$ \\
\hline LA PARGUERA & NE CARIBBEAN & $67^{\circ} \mathrm{W}$ & $17.9^{\circ} \mathrm{N}$ \\
\hline LOS ROQUES & SE CARIBBEAN & $67^{\circ} \mathrm{W}$ & $12^{\circ} \mathrm{N}$ \\
\hline MARGARITA & SE CARIBBEAN & $65^{\circ} \mathrm{W}$ & $11^{\circ} \mathrm{N}$ \\
\hline MISKITO & SW CARIBBEAN & $83^{\circ} \mathrm{W}$ & $14.5^{\circ} \mathrm{N}$ \\
\hline PORTOBELO & SW CARIBBEAN & $80^{\circ} \mathrm{W}$ & $9.5^{\circ} \mathrm{N}$ \\
\hline PUERTO PLATA & NE CARIBBEAN & $71^{\circ} \mathrm{W}$ & $20^{\circ} \mathrm{N}$ \\
\hline REINA & NW CARIBBEAN & $79^{\circ} \mathrm{W}$ & $20.5^{\circ} \mathrm{N}$ \\
\hline ROATAN & NW CARIBBEAN & $86.5^{\circ} \mathrm{W}$ & $16.5^{\circ} \mathrm{N}$ \\
\hline SAN BLAS & SW CARIBBEAN & $78^{\circ} \mathrm{W}$ & $9.5^{\circ} \mathrm{N}$ \\
\hline SAN JUAN & NE CARIBBEAN & $66.5^{\circ} \mathrm{W}$ & $18.6^{\circ} \mathrm{N}$ \\
\hline SANTA CLARA & NW CARIBBEAN & $80^{\circ} \mathrm{W}$ & $23^{\circ} \mathrm{N}$ \\
\hline SANTIAGO & NW CARIBBEAN & $76^{\circ} \mathrm{W}$ & $19.5^{\circ} \mathrm{N}$ \\
\hline ST. LUCIA & SE CARIBBEAN & $60.9^{\circ} \mathrm{W}$ & $13.7^{\circ} \mathrm{N}$ \\
\hline ST. THOMAS/ST. JOHN & NE CARIBBEAN & $64.7^{\circ} \mathrm{W}$ & $18.2^{\circ} \mathrm{N}$ \\
\hline ST. KITTS/NEVIS & NE CARIBBEAN & $62.9^{\circ} \mathrm{W}$ & $17.4^{\circ} \mathrm{N}$ \\
\hline TRINIDAD/TOBAGO & SE CARIBBEAN & $61^{\circ} \mathrm{W}$ & $11^{\circ} \mathrm{N}$ \\
\hline
\end{tabular}

Recorded pixels were selected to read SST offshore to avoid any direct contamination from terrestrial influences and to approximate average fore reef slope SSTs for each month. 
TABLE 2

The coral reef sites of the North and South Atlantic Ocean that have been selected for this study $(N=15)$

ATLANTIC REEF SITES (N=15)

$\begin{array}{lccc}\text { Reef Site } & \text { Location } & \text { Longitude } & \text { Latitude } \\ \text { Abrolhos } & \text { S. Atlantic } & 39^{\circ} \mathrm{W} & 18^{\circ} \mathrm{S} \\ \text { Arrial do Cabo } & \text { S. Atlantic } & 41.5^{\circ} \mathrm{W} & 23^{\circ} \mathrm{S} \\ \text { Bermuda } & \text { N. Atlantic } & 62.8^{\circ} \mathrm{W} & 32.4^{\circ} \mathrm{N} \\ \text { Fernando de Norohna } & \text { S. Atlantic } & 33^{\circ} \mathrm{W} & 3.6^{\circ} \mathrm{S} \\ \text { Flower Gardens } & \text { Gulf of Mexico } & 94^{\circ} \mathrm{W} & 29^{\circ} \mathrm{N} \\ \text { Grand Turk } & \text { N. Atlantic } & 72^{\circ} \mathrm{W} & 22^{\circ} \mathrm{N} \\ \text { Key West } & \text { N. Atlantic } & 81.5^{\circ} \mathrm{W} & 24.5^{\circ} \mathrm{N} \\ \text { Nassau } & \text { N. Atlantic } & 77.4^{\circ} \mathrm{W} & 24.8^{\circ} \mathrm{N} \\ \text { Praia } & \text { NE. Atlantic } & 23.4^{\circ} \mathrm{W} & 15.1^{\circ} \mathrm{N} \\ \text { Recife } & \text { S. Atlantic } & 34.3^{\circ} \mathrm{W} & 8.5^{\circ} \mathrm{S} \\ \text { Salvador } & \text { S. Atlantic } & 38^{\circ} \mathrm{W} & 13^{\circ} \mathrm{S} \\ \text { San Salvador } & \text { N. Atlantic } & 74.5^{\circ} \mathrm{W} & 24.4^{\circ} \mathrm{N} \\ \text { Sao Sebastiano } & \text { S. Atlantic } & 46^{\circ} \mathrm{W} & 24.1^{\circ} \mathrm{S} \\ \text { Sao Tome } & \text { NE. Atlantic } & 6.7^{\circ} \mathrm{E} & 0.2^{\circ} \mathrm{N} \\ \text { Tampico } & \text { Gulf of Mexico } & 97.5^{\circ} \mathrm{W} & 22^{\circ} \mathrm{N}\end{array}$

TABLE 3

Trend line statistics for the reduced database for Caribbean and Atlantic reef sites in the GCRA database

CORAL REEF SITE

LINEAR REGRESSION

FORMULA

Abrohlos, BRAZIL

ANGUILLA

ANTIGUA

Arrial do Cabo, BRAZIL

ARUBA

BARBADOS

BARBUDA

BELIZE - south

BELIZE - Glover's

BELIZE - north

BERMUDA

Bocas del Toro, PANAMA

BONAIRE, N.A. $y=0.0014 x+25.961$

$y=0.0033 x+26.679$

$y=0.0032 x+26.817$

$\mathrm{y}=0.0011 \mathrm{x}+24.562$

$y=0.0026 x+26.73$

$\mathrm{y}=0.0034 \mathrm{x}+26.982$

$y=0.0033 x+26.703$

$\mathrm{y}=0.0028 \mathrm{x}+27.376$

$\mathrm{y}=0.0027 \mathrm{x}+27.367$

$\mathrm{y}=0.0024 \mathrm{x}+27.391$

$y=0.0042 x+22.411$

$y=0.0038 x+27.438$

$y=0.0019 x+26.933$
COEFFICIENT $\left(\mathrm{R}^{2}\right)$

0.0062

0.0523

0.056

0.0023

0.0359

0.0769

0.0564

0.0422

0.0379

0.0325

0.0111

0.1479

0.0223 
TABLE 3 (Continue)

Trend line statistics for the reduced database for Caribbean and Atlantic reef sites in the GCRA database

CORAL REEF SITE

Cartagena, COLOMBIA

Cayo Largo, CUBA

Chinchorro, MEXICO

Cozumel, MEXICO

CURACAO, N.A.

Fernando de Norohna, BRAZIL

Key West, FL, USA

Flower Gardens, LA, USA

Grand Cayman, CAYMAN

Grand Turk, TURKS \& CAICOS

GRENADA

HAITI

Negril, JAMAICA

Discovery Bay, JAMAICA

La Parguera, PR, USA

Los Roques, VENEZUELA

Miskito, NICARAGUA

Margarita, VENEZUELA

Nassau, BAHAMAS

Portobelo, PANAMA

Praia, CAPE VERDE

Puerto Plata, DOM. REP.

Recife, BRAZIL

Reina, CUBA

Roatan, HONDURAS

Salvador, BRAZIL

San Blas, PANAMA

San Juan, PR, USA

San Salvador, BAHAMAS

Santa Clara, CUBA

Santiago, CUBA

Sao Sebastiano, BRAZIL

SAO TOME

St. Thomas/St. John, USVI, USA
FORMULA

\section{LINEAR REGRESSION}

COEFFICIENT $\left(\mathrm{R}^{2}\right)$

$y=0.0048 x+26.886$

0.1215

$y=0.0018 x+27.585$

0.0093

$y=0.0023 x+27.406$

0.0269

$\mathrm{y}=0.0011 \mathrm{x}+27.558$

0.0052

$y=0.0022 x+26.914$

0.0302

$y=0.001 x+27.256$

0.0077

$y=0.002 x+26.398$

0.0046

$y=-0.0006 x+23.898$

0.0001

$\mathrm{y}=0.0024 \mathrm{x}+27.586$

0.0225

$\mathrm{y}=0.0052 \mathrm{x}+26.333$

0.0766

$\mathrm{y}=0.0031 \mathrm{x}+27.043$

0.0602

$y=0.0005 x+26.984$

0.1

$\mathrm{y}=0.0027 \mathrm{x}+27.636$

0.0377

$\mathrm{y}=0.0024 \mathrm{x}+27.675$

0.0273

$y=0.0033 x+27.011$

0.0543

$\mathrm{y}=0.0011 \mathrm{x}+26.95$

0.0062

$y=0.0028 x+27.467$

0.0639

$\mathrm{y}=0.0009 \mathrm{x}+26.794$

0.0037

$y=0.003 x+26.221$

0.0116

$y=0.0032 x+27.446$

0.097

$\mathrm{y}=0.007 \mathrm{x}+23.22$

0.0722

$y=0.0048 x+26.605$

0.0907

$y=0.0003 x+27.409$

0.0009

$\mathrm{y}=0.002 \mathrm{x}+27.664$

0.0125

$\mathrm{y}=0.0031 \mathrm{x}+27.339$

0.0538

$y=-0.0003 x+27.179$

0.0003

$\mathrm{y}=0.0045 \mathrm{x}+27.255$

0.1439

$\mathrm{y}=0.0038 \mathrm{x}+26.69$

0.0632

$y=0.0034 x+26.088$

0.0197

$y=0.0041 x+26.528$

0.0314

$y=0.0023 x+27.666$

0.0227

$y=0.0027 x+23.067$

0.071

$\mathrm{y}=0.0026 \mathrm{x}+26.485$

0.0153

$y=0.0032 x+26.855$

0.0498 
TABLE 3 (Continue)

Trend line statistics for the reduced database for Caribbean and Atlantic reef sites in the GCRA database

CORAL REEF SITE

ST KITTS \& NEVIS

\section{ST. LUCIA}

Tampico, MEXICO

TRINIDAD \& TOBAGO
FORMULA

LINEAR REGRESSION

COEFFICIENT $\left(\mathrm{R}^{2}\right)$

$$
\begin{gathered}
y=0.0032 x+26.814 \\
y=0.0033 x+27.012 \\
y=0.002 x+25.783 \\
y=0.003 x+27.061
\end{gathered}
$$

0.0069

0.0036

0.0576

Trend line statistics for Caribbean and Atlantic reef sites in the GCRA database. These values allow comparisons to be made between or among SST trends. The $\mathrm{R}^{2}$ value indicates the relative strength of the correlation between temperature and time in the reduced data series for each site.

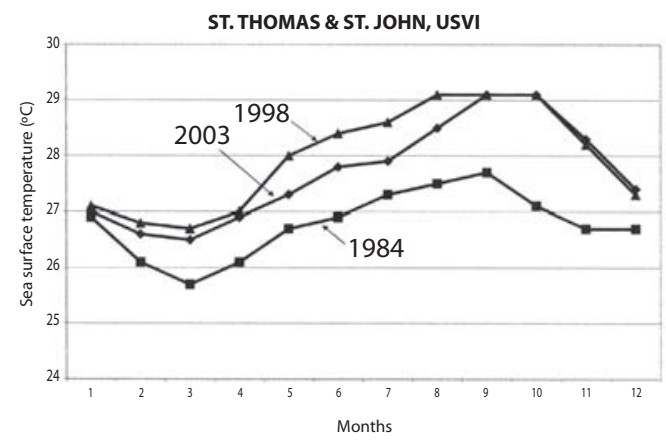

Fig. 2. The monthly SST data for St. Thomas/St. John during three years within the period of this survey are shown ranging from \#1 (January) through \#12 (December) for each year. 1984 is presented from the beginning of the multi-year trend. 2003 represents the end of the trend. 1998 is selected as an El Niño year to provide a comparison of monthly data to the other two years, but especially to 2003, a non-El Niño year.

positive slope indicative of gradual warming (Fig. 3). These reduced data indicate the gradual escalation of sea surface temperatures over the past two decades that is consistent with the phenomenon generally referred to as "global warming" by the scientific community and the lay public (Hansen et al. 2005).

The complete set of reduced SST data for the Caribbean and Atlantic regions is included in figures 5-11. Each of the graphic displays shows a positive slope for the linear trend

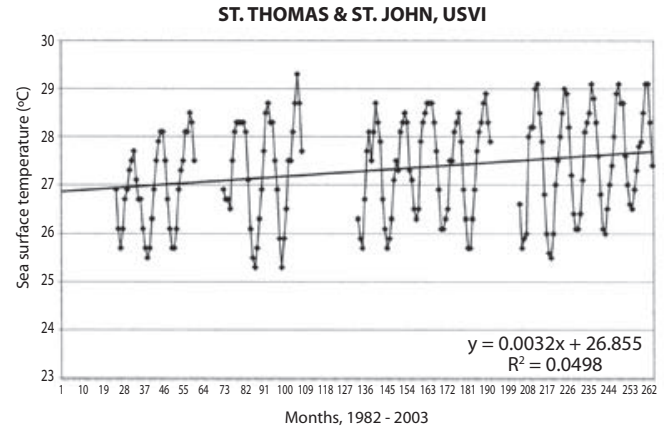

Fig. 3. Reduced SST database for St. Thomas/St. John in which monthly records for six complete years have been removed from the full database of 1982-2003 (compare to Fig. 1). The years removed were those in which volcanic eruptions occurred and ones during which an El Niño event was ongoing. In 1982, El Chichon (Mexico) erupted; in 1991, Mt. Pinatubo (Phillipines) erupted. These years were characterized by lower than average temperatures in the global path of discharged gases and suspended aerosols. The four El Niño years of 1983, 1987, 1992 and 1998 were characterized by accelerated warming of the atmosphere and surface ocean throughout the Caribbean basin. Months \#25-36 represent 1984; months \#37-48, 1985.

line, except in the Flower Gardens site in the Gulf of Mexico and Salvador, Brazil. Those sites showing more positive slopes are those that would be experiencing greater heat stress. Two aspects of the warming trend are ecologically important. First would be the absolute high temperature reached at the site. Second would be the duration of exposure to that 
high temperature. The worst-case scenario for coral reef bleaching would be a site that reached a temperature greater than the local bleaching threshold and that sustained such a temperature for several months. The cool season temperature, however, is important for recovery from coral reef bleaching. At sites where cool seasonal temperatures are insufficient for recovery, the bleaching response may be prolonged and may still be evident at the beginning of the next warm season. In that case, such sites will show persistent coral reef bleaching as unresolved episodes accumulate (Goreau \& Hayes 1995). Such prolonged bleached reefs will show impaired coral skeletal growth, metabolism, reproduction, and defense against predation, as long as living corals remain in the reef tract.

The trendlines for the upper and lower extremes of temperature to which the reefs of St. Thomas/St. John have been exposed both have a positive slope for the 20-year period in this study (Fig. 4). The summer warming, however, is changing at a rate $\left(0.07^{\circ} \mathrm{C} /\right.$ year $)$ faster than the winter warming $\left(0.04^{\circ} \mathrm{C} /\right.$ year $)$. This may mean that after the reef is thermally stressed in the summer, winter relief might be insufficient to assure recovery. The stage would then be set for a bleached reef to remain bleached from year to year because of incomplete recovery during winter seasons of insufficiently cooler temperatures.

The comparison of thermal ranges seen by various reefs indicates that the range of exposure to temperature during the course of the year varies considerably among different reef sites (Fig. 12). For those reefs with much wider ranges of temperature exposure, thermal relief may be experienced during cooler months. Note that the maximum temperatures for the database reef sites (dark grey line) range from $25-35^{\circ} \mathrm{C}$. However, the cool season lows (light grey line) are far more variable from site to site. Notice that the variance of maxima is small, but there are very large variances for minima.

Another comparison that the database offers is that of examining Caribbean sites at identical longitudes. The Caribbean basin is inherently complex in both geographic and oceanographic features. Nevertheless, comparisons between and among sites may be made using the SST data. Figure 13 (top) shows an overlap of trends for two eastern Caribbean sites. From the northeastern Caribbean, Antigua is shown at $17^{\circ} \mathrm{N}$ and $62^{\circ} \mathrm{W}$. From the southeastern Caribbean, Grenada is shown at $12^{\circ} \mathrm{N}$ and $62^{\circ} \mathrm{W}$. Figure 13 (bottom) compares two sites from the western Caribbean. The northwestern basin is represented by Santa Clara, Cuba at $23^{\circ} \mathrm{N}$ and $80^{\circ} \mathrm{W}$. The southwestern site is Portobelo, Panama at $9.5^{\circ} \mathrm{N}$ and $80^{\circ} \mathrm{W}$.

Also, Caribbean sites may be compared that lie at equivalent latitudes. In Figure 14 (top), the northwestern site of Glover's Reef in Belize at $17.4^{\circ} \mathrm{N}$ and $88^{\circ} \mathrm{W}$ is displayed. The contrasting northeastern site is St. Kitts/Nevis at $17.4^{\circ} \mathrm{N}$ and $62.9^{\circ} \mathrm{W}$. Two sites from the south are compared in Figure 14 (bottom). From the southwest, Cartagena, Colombia is shown at $11^{\circ} \mathrm{N}$ and $75.5^{\circ} \mathrm{W}$. From the southeastern region, Trinidad/ Tobago is shown at $11^{\circ} \mathrm{N}$ and $61^{\circ} \mathrm{W}$.

The SST data recorded from the paired coral reef sites of matching latitudes or longitudes allow the development of a synoptic presentation of regional differentials (Figs. 13, 14). The Western Caribbean experienced anomalous warm summer temperatures in 1987, 1989, 1993, 1994,

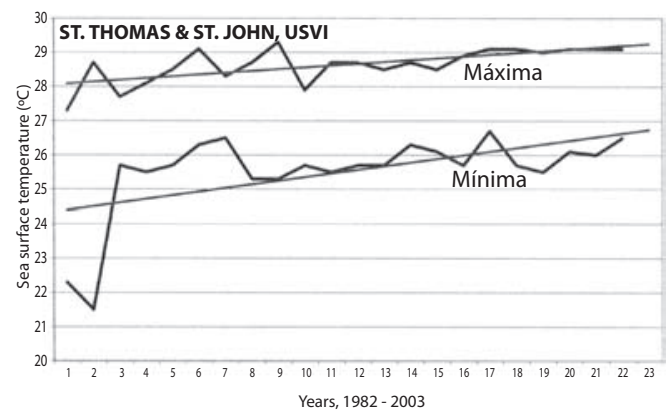

Fig. 4. From the 1984-2003 St. Thomas/St. John database, the highest or maximum temperature recorded each year and the lowest or minimum temperature recorded each year have been displayed. Note that both the minimum and maximum trend lines show positive slopes, indicating gradual warming of both warm \& cool seasonal temperatures. The range of thermal differentials per year is $1.8-4.0^{\circ} \mathrm{C}$ with a mean of $2.78^{\circ} \mathrm{C}$. 

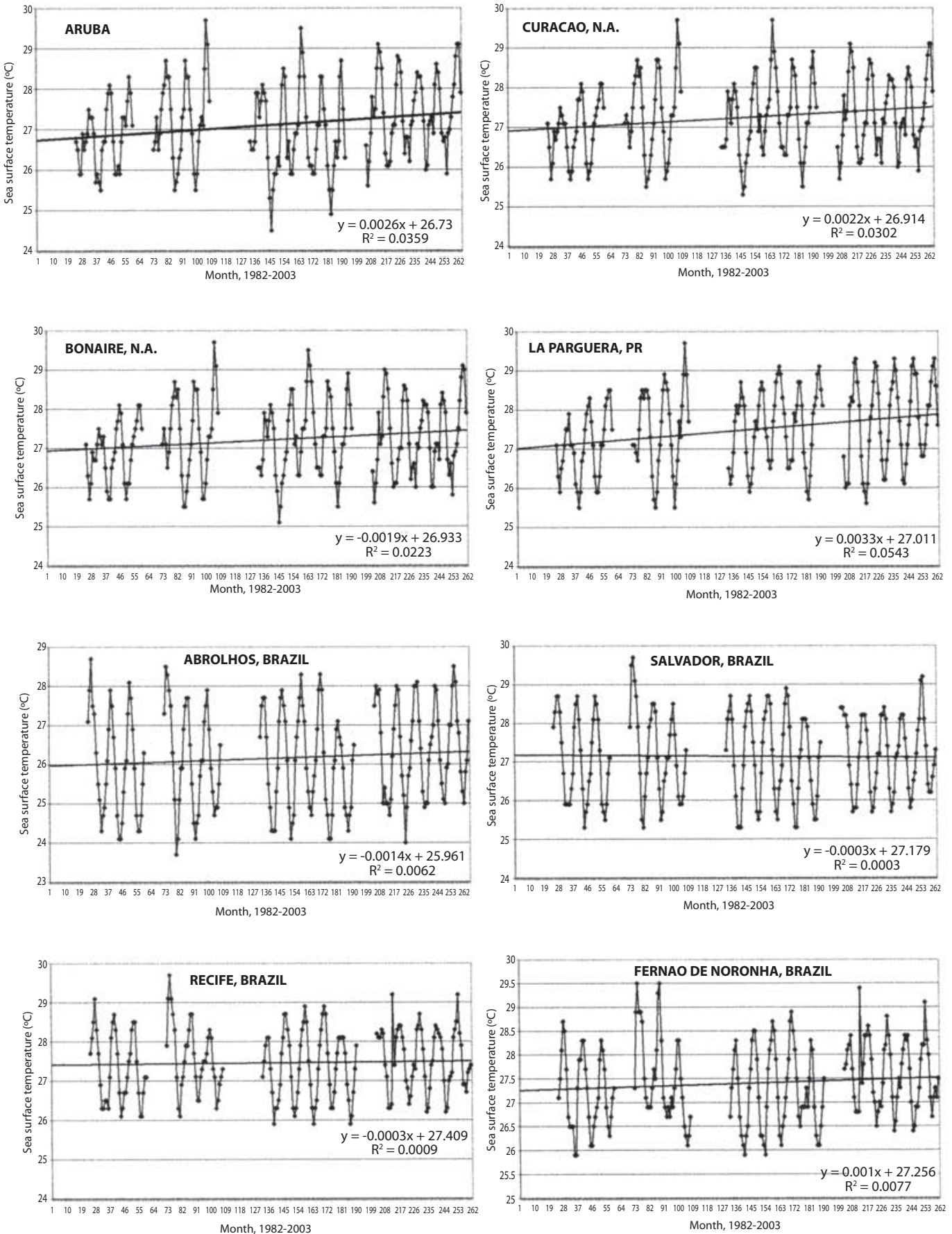

Fig. 5. Caribbean and Atlantic reef site data from the GCRA SST database. Graphic displays of sea surface temperatures in degrees Centigrade are plotted versus time in months from 1984-2003, with ENSO and volcanic eruption years omitted. The named reef site is listed above the graph; the linear trend equation and regression coefficient $\left(\mathrm{R}^{2}\right)$ are listed at the base of the graph. 

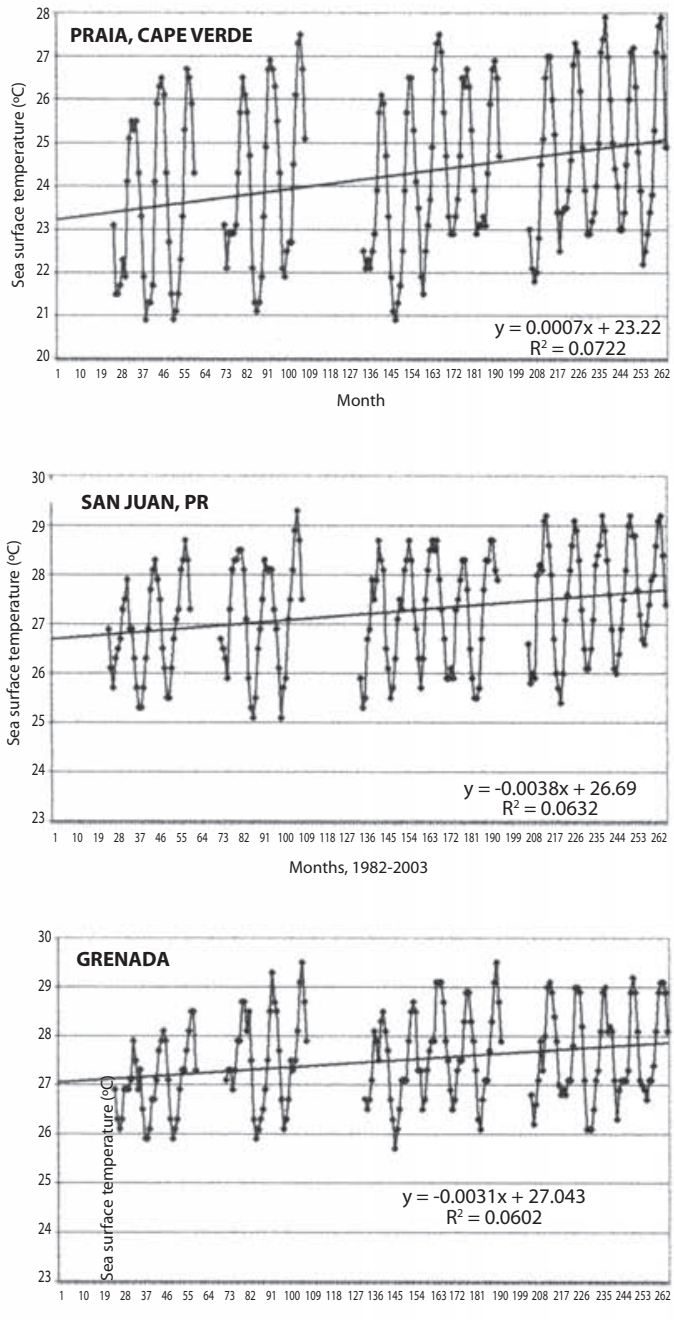

Months, 1982-2003

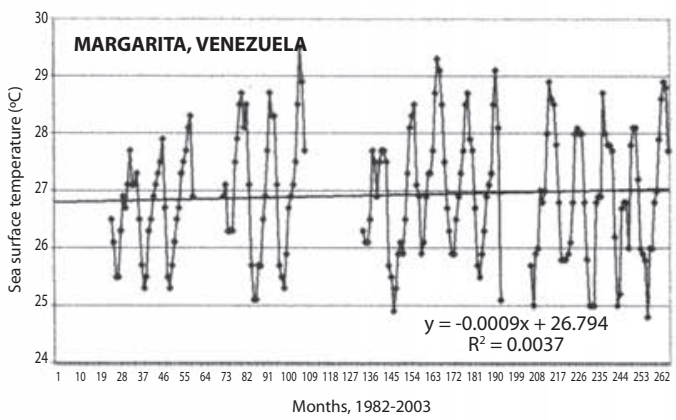

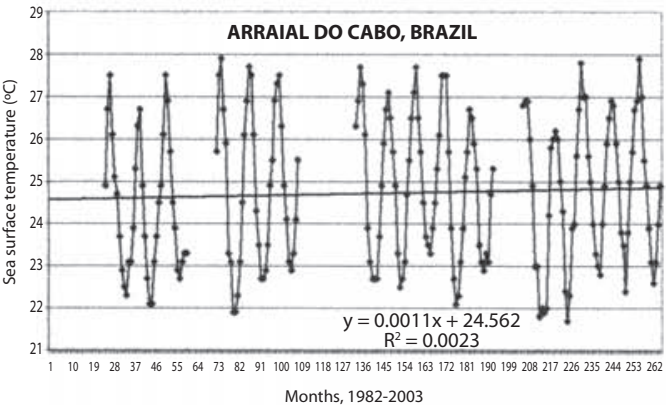
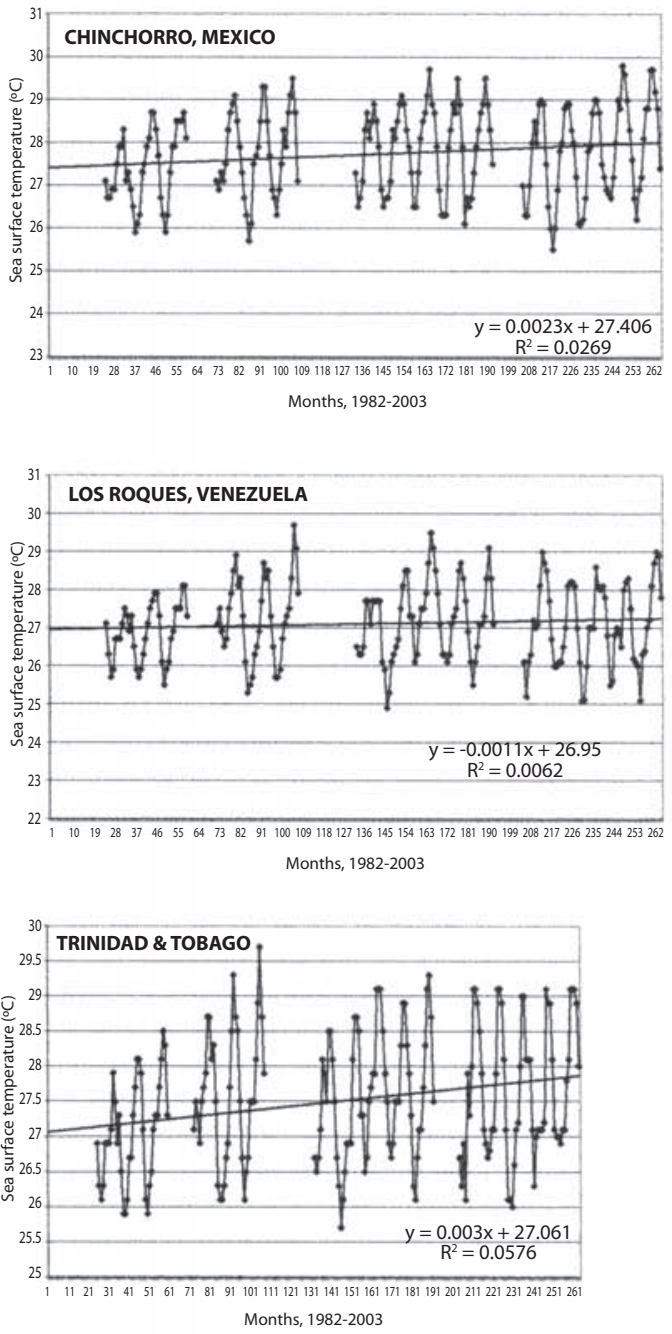

Fig. 6. Caribbean and Atlantic reef site data from the GCRA SST database. Graphic displays of sea surface temperatures in degrees Centigrade are plotted versus time in months from 1984-2003, with ENSO and volcanic eruption years omitted. The named reef site is listed above the graph; the linear trend equation and regression coefficient $\left(\mathrm{R}^{2}\right)$ are listed at the base of the graph. 

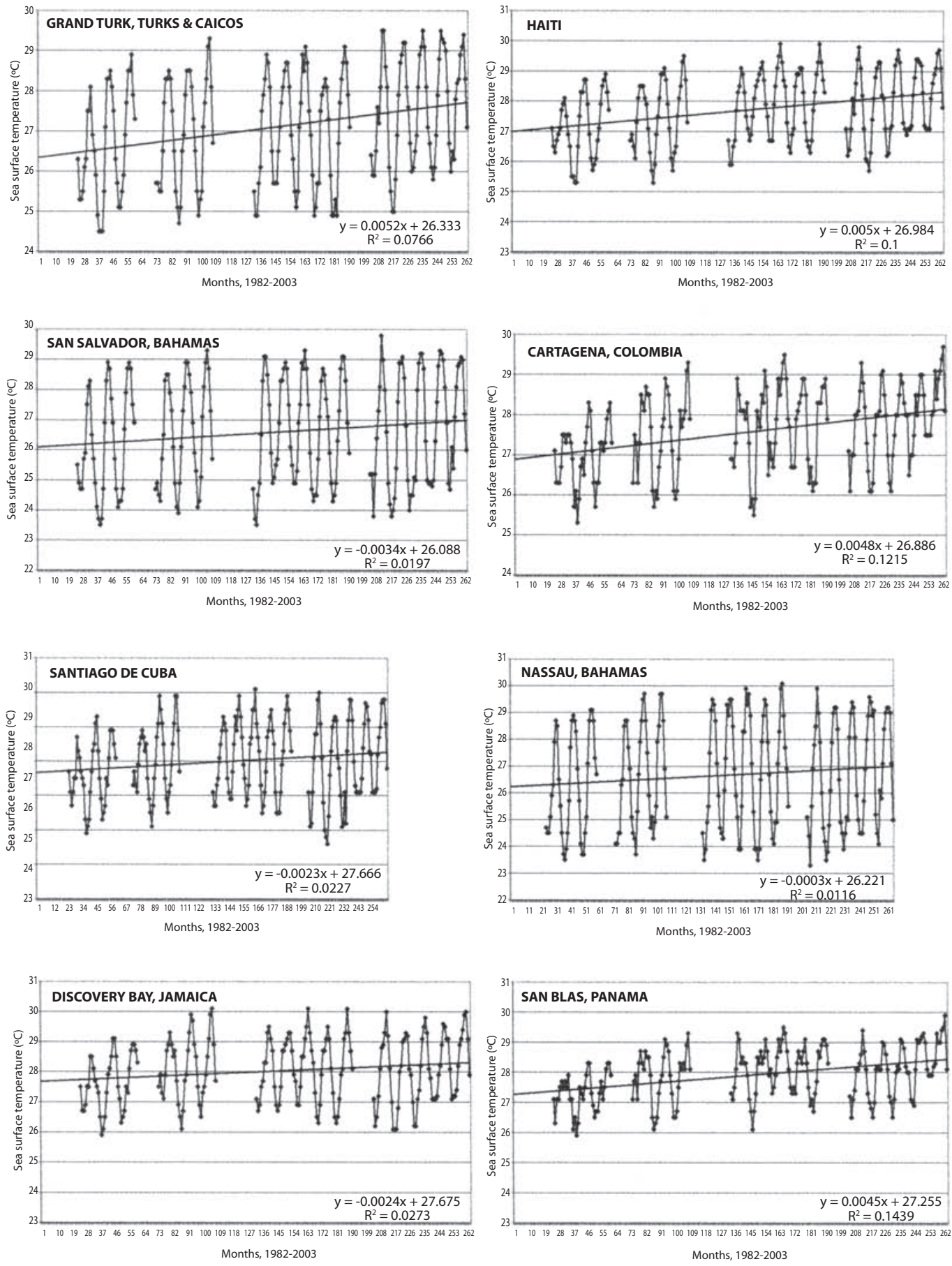

Fig. 7. Caribbean and Atlantic reef site data from the GCRA SST database. Graphic displays of sea surface temperatures in degrees Centigrade are plotted versus time in months from 1984-2003, with ENSO and volcanic eruption years omitted. The named reef site is listed above the graph; the linear trend equation and regression coefficient $\left(\mathrm{R}^{2}\right)$ are listed at the base of the graph. 

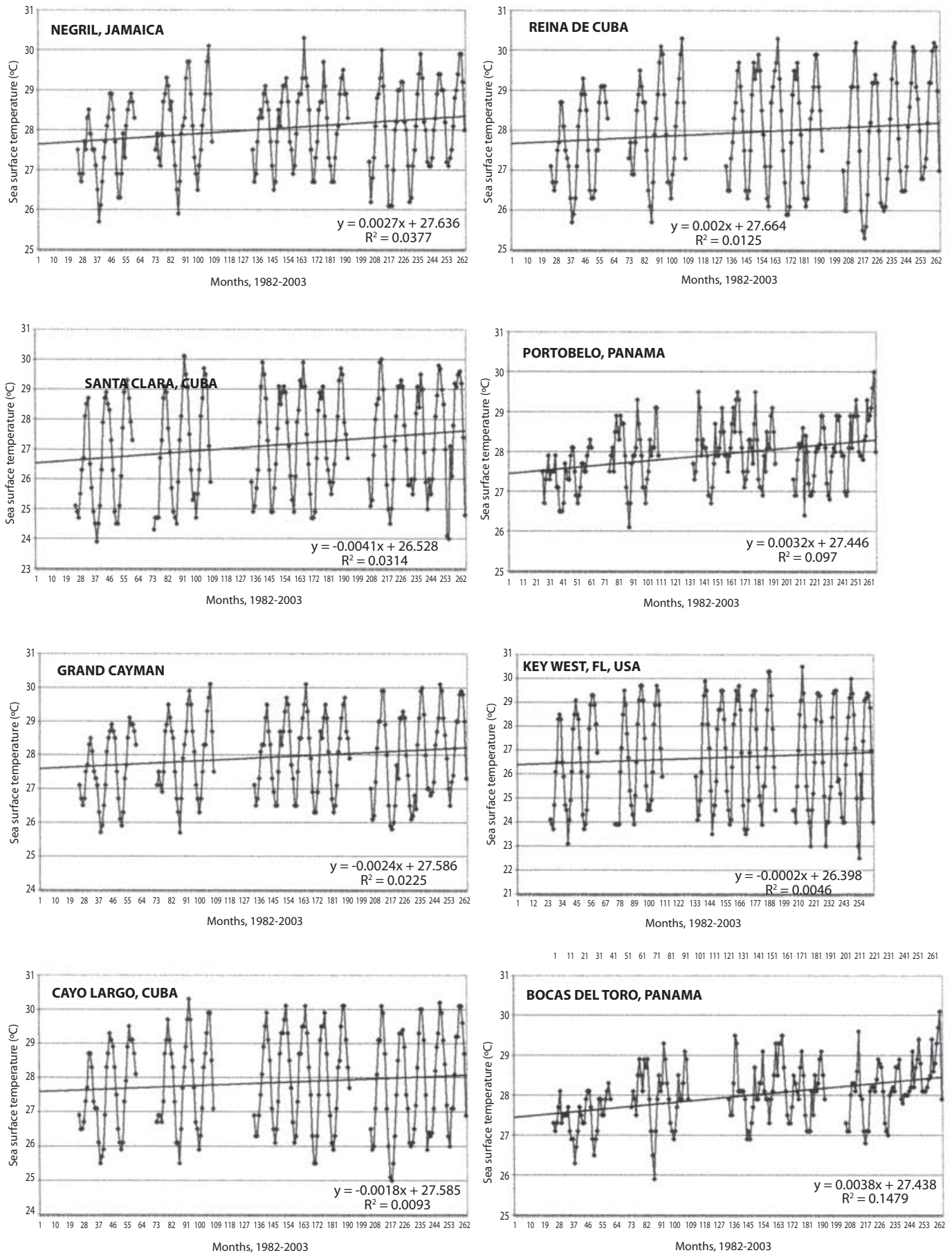

Fig. 8. Caribbean and Atlantic reef site data from the GCRA SST database. Graphic displays of sea surface temperatures in degrees Centigrade are plotted versus time in months from 1984-2003, with ENSO and volcanic eruption years omitted. The named reef site is listed above the graph; the linear trend equation and regression coefficient $\left(\mathrm{R}^{2}\right)$ are listed at the base of the graph. 

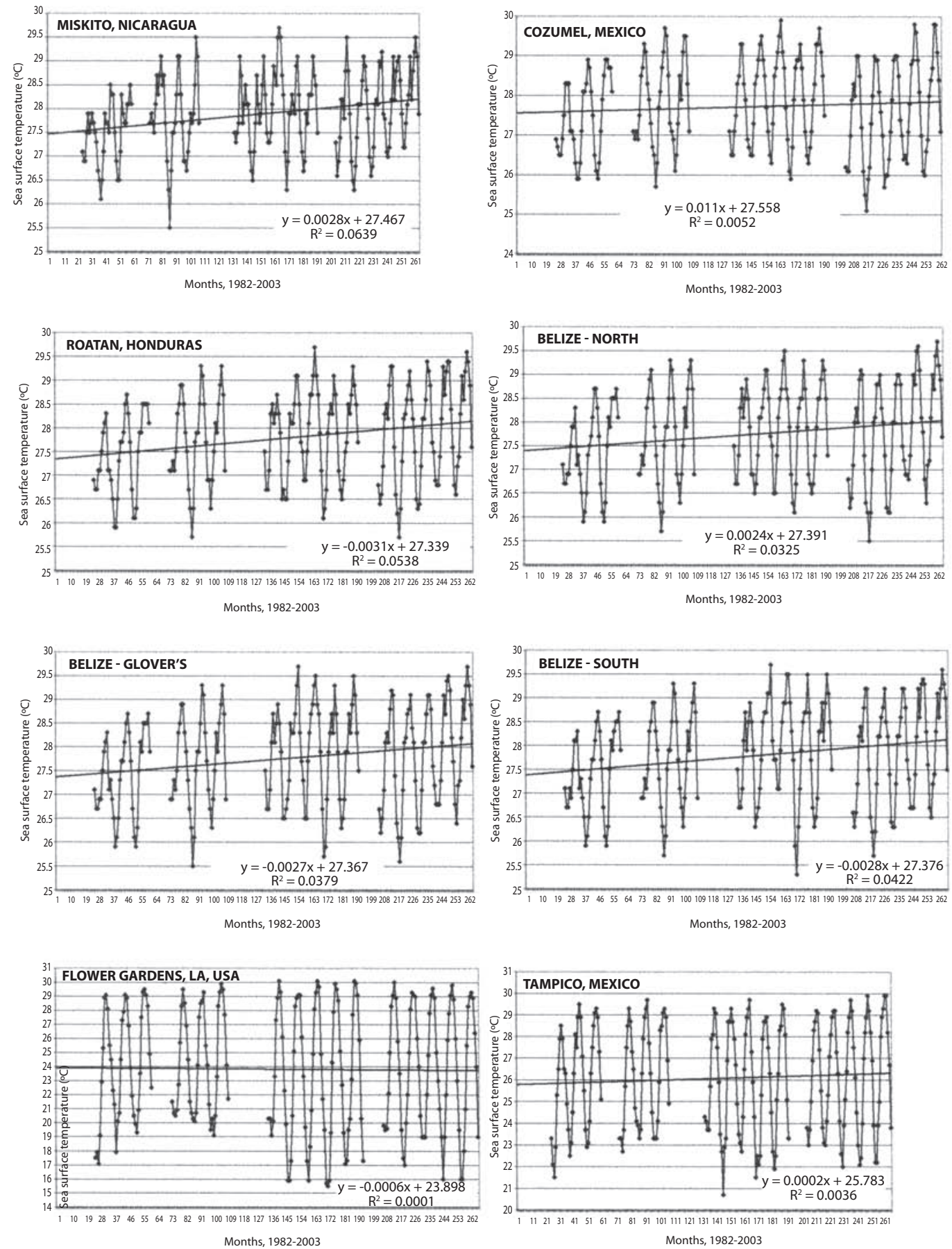

Fig. 9. Caribbean and Atlantic reef site data from the GCRA SST database. Graphic displays of sea surface temperatures in degrees Centigrade are plotted versus time in months from 1984-2003, with ENSO and volcanic eruption years omitted. The named reef site is listed above the graph; the linear trend equation and regression coefficient $\left(\mathrm{R}^{2}\right)$ are listed at the base of the graph. 

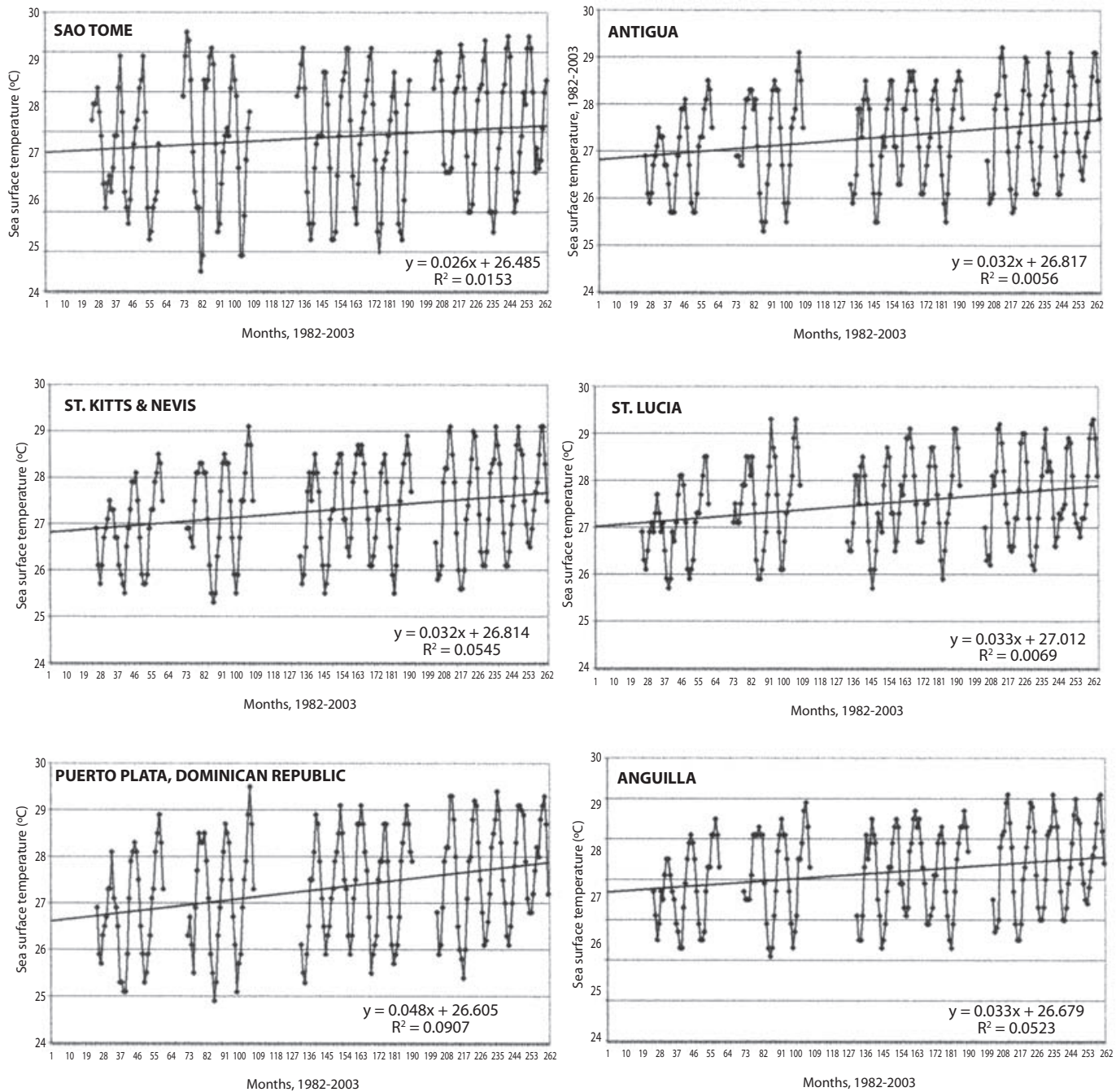

Fig. 10. Caribbean and Atlantic reef site data from the GCRA SST database. Graphic displays of sea surface temperatures in degrees Centigrade are plotted versus time in months from 1984-2003, with ENSO and volcanic eruption years omitted. The named reef site is listed above the graph; the linear trend equation and regression coefficient $\left(\mathrm{R}^{2}\right)$ are listed at the base of the graph.

1995, 1997, 1998, 1999 and 2003. The only year when SSTs for each of the two sites in the north and south were elevated was 2003. In 1987 and 1998, only the northwestern sector was very hot. In 1989, a northern site (Cuba) and a southern site (Colombia) were hot. In 1994, one northern (Belize) and one southern (Colombia) site were hot. Belize, in the northwestern region was also warm in 1995 and 1997. The higher latitude sites of Belize and Cuba experienced summertime warming more frequently than the southwestern sites of Panama and Colombia.

The eastern Caribbean had its warmest summer temperatures in 1989, 1990 and 1997. However, in 1994 and 1996, as well as in 2003, the lower latitude Caribbean site of Trinidad/ Tobago also had warm summer temperatures. Relatively cooler SSTs were recorded for the southern quadrant from 1991-1996 and cool temperatures in the northern quadrant 

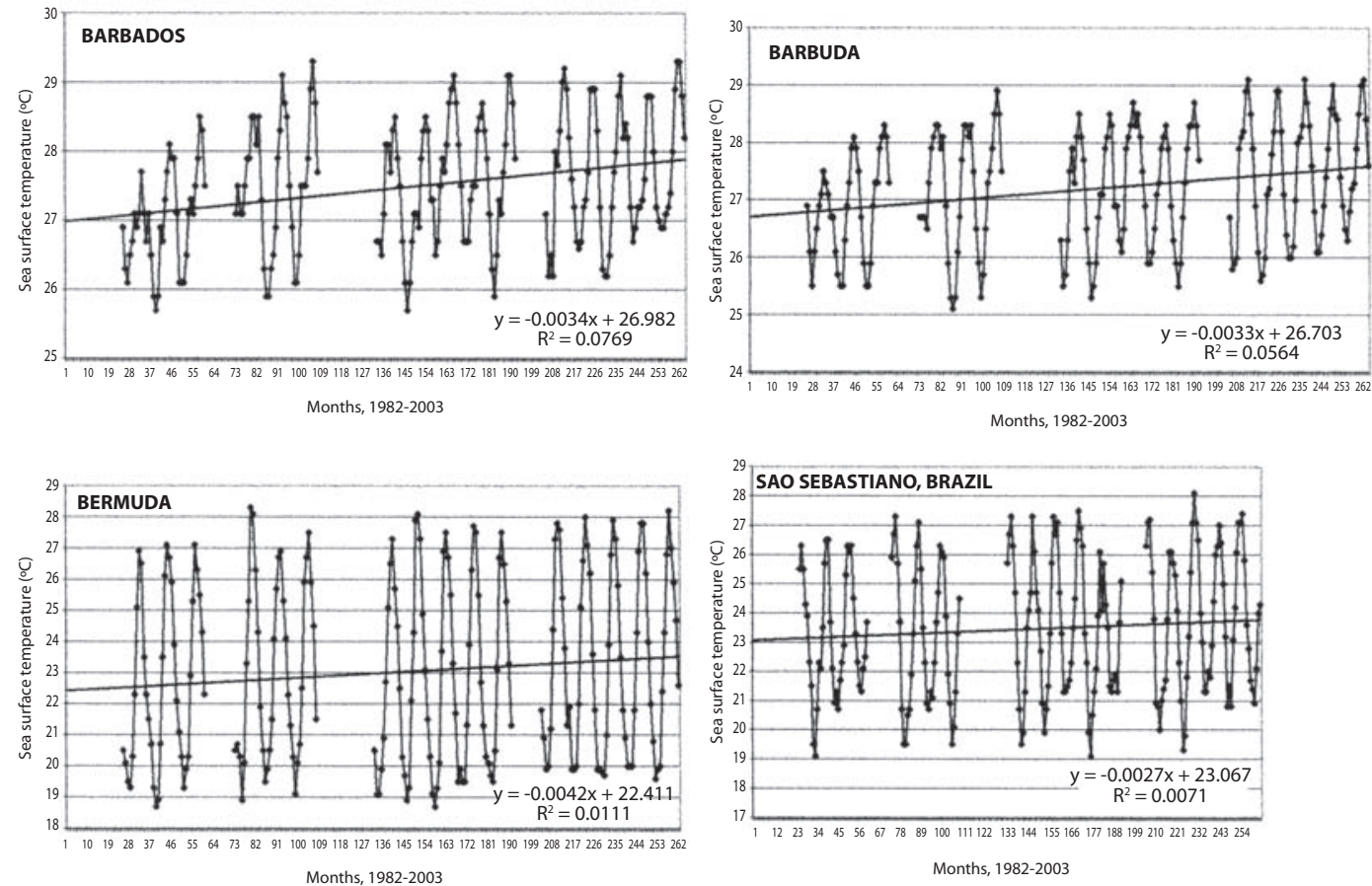

Fig. 11. Caribbean and Atlantic reef site data from the GCRA SST database. Graphic displays of sea surface temperatures in degrees Centigrade are plotted versus time in months from 1984-2003, with ENSO and volcanic eruption years omitted. The named reef site is listed above the graph; the linear trend equation and regression coefficient $\left(\mathrm{R}^{2}\right)$ are listed at the base of the graph.

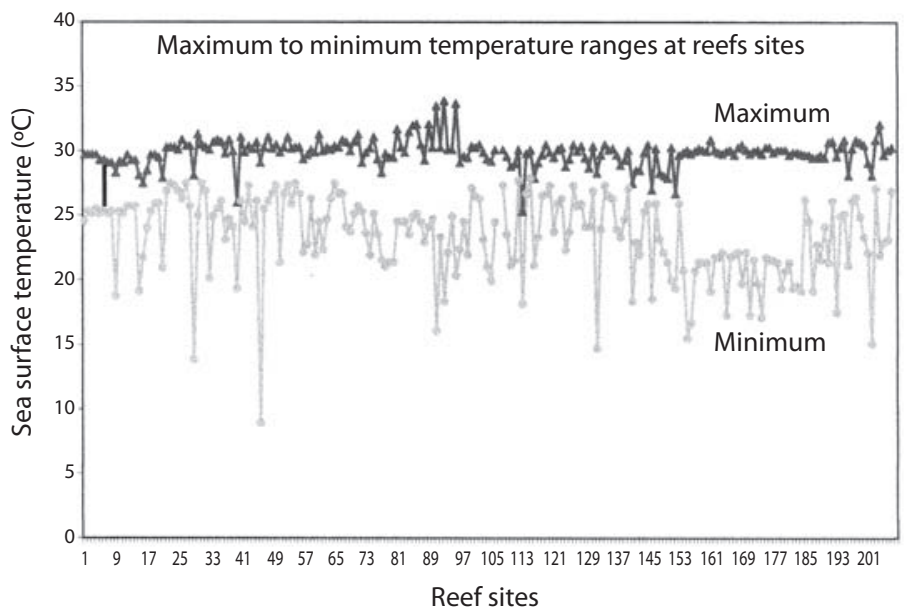

Fig. 12. The range of maximum (dark grey) to minimum (light grey) temperature exposures for the proxy St. Thomas / St. John, U.S. Virgin Island reef site (the vertical black line at reef site \#5) shown in relationship to other tropical reef sites from the global GCRA database. Notice the wide ranges among sites and the heightened variability of the minima (cool seasonal lows) relative to maxima (warm seasonal highs). 

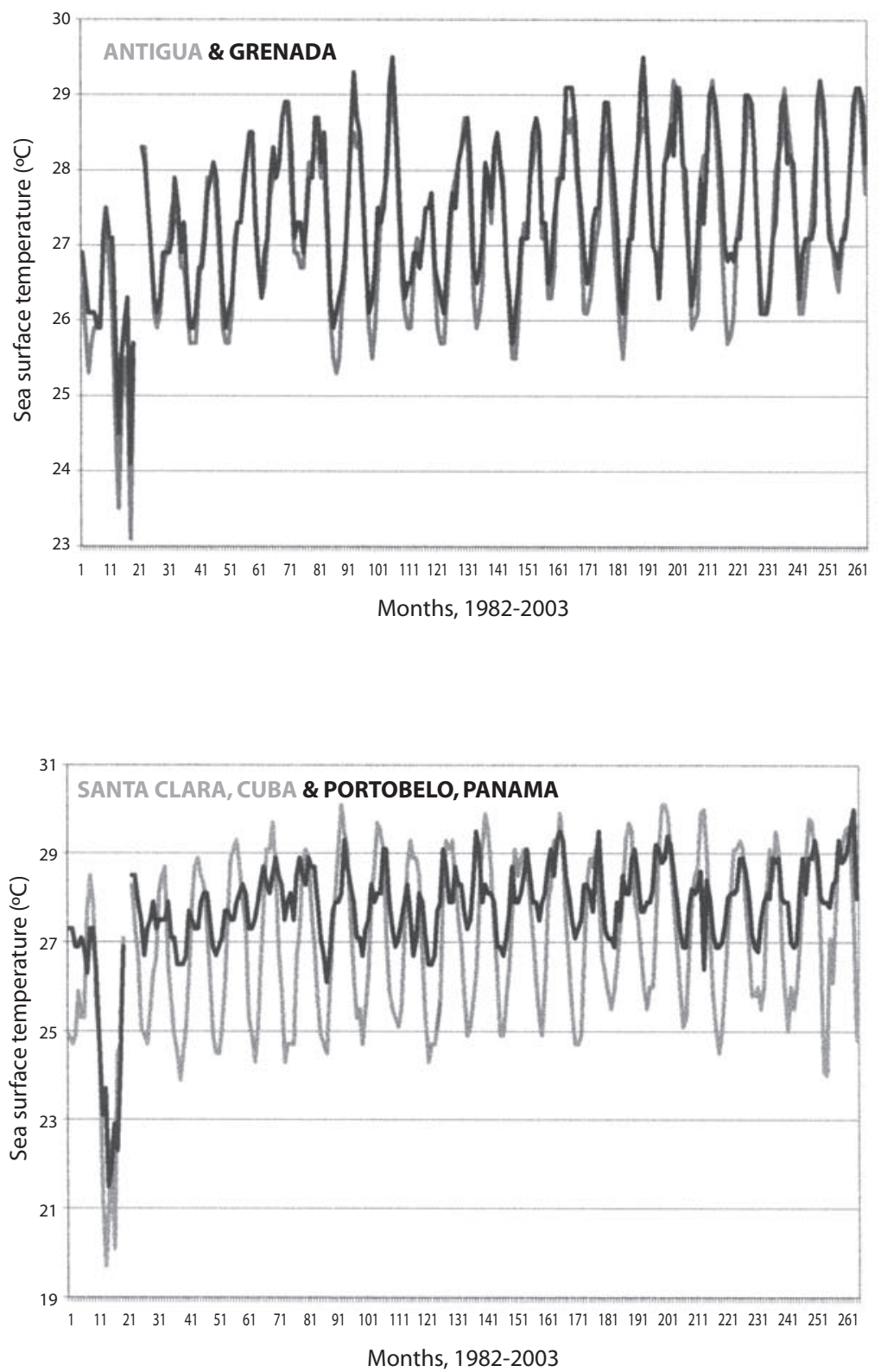

Fig. 13. A comparison of SST records for paired Caribbean reef sites from the same longitude, but different latitudes: Top, from sites at $62{ }^{\circ} \mathrm{W}$ (Antigua and Grenada); Bottom, from sites at $80^{\circ} \mathrm{W}$ (Portobelo, Panama and Santa Clara, Cuba).

characterized the years, 1988-1989, 1989-1990, 1990-1991, 1991-1992 and 1992-1993.

Wintertime warming temperatures that failed to reach $26^{\circ} \mathrm{C}$ were recorded in the northwest (Cuba) for 1996-1997, 1997-1998 and 2000-2001. In the northeastern region (St.
Kitts), similar warm winter temperatures were recorded for 1986-1987, 1987-1988, 1995-1996 and 1997-1998. Otherwise, cooler winter SSTs of less than $26^{\circ} \mathrm{C}$ were recorded for the southeastern Caribbean (Trinidad) in 1985-1986, 1993-1994, 1996-1997 and 2002-2003. 

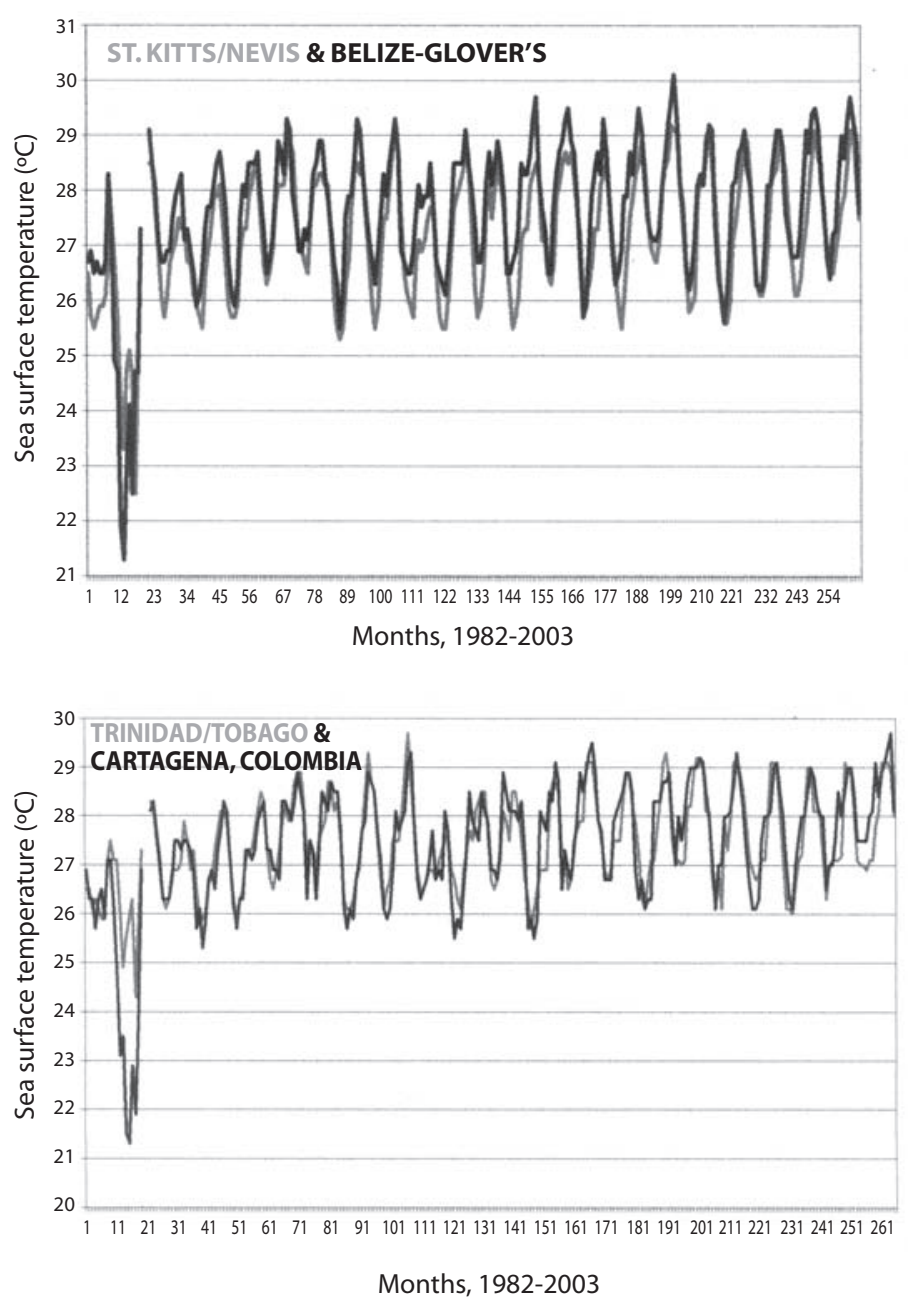

Fig. 14. A comparison of SST records for paired Caribbean sites from the same latitude, but different longitudes: Top, from sites at $17.4^{\circ} \mathrm{N}$ (Glover's Reef. Belize and St. Kitts/Nevis); Bottom, from sites at $11^{\circ} \mathrm{N}$ (Trinidad \&Tobago and Cartagena, Colombia).

Efforts to identify clear patterns from the analysis of sea surface temperatures in space and time within a defined region have led to the awareness that there is extensive sub-regional variability in thermal distribution. The Western Caribbean is warming faster than is the Eastern Caribbean. The Northwestern sector has been the sub-region of most anomalous and most frequent SST elevation. The Southeastern Caribbean, by contrast, has been the area of greatest winter cooling.

\section{DISCUSSION}

The Intergovernmental Panel on Climate Change (IPCC) Report of February 2, 2007 (Alley et al. 2007) indicated that scientific consensus has been reached on several issues unresolved from previous reports. First, observed changes in climate are now considered due to human activity, and not to natural causes. Second, no discrepancy exists between surface and satellite temperature data. This means that SST data, such as the GCRA coral reef 
database, would most likely be considered to be representative of or nearly equivalent to in situ records (Strong et al. 2000). Third, most scientists agree that significant reductions in greenhouse gas emissions will be required to limit projected future changes in climate.

From our analysis of reef site SSTs, it is clear that the annual SST record is not identical from year to year at any site. Moreover, the SST record may fluctuate from year to year at a single site and may be markedly different between sites. The regression correlations in Table 3 for the reduced database can be used to rank order the strength of the correlation of temperature with time. Were these data seasonally de-trended to remove the annual variability, these $\mathrm{R}^{2}$ values would be much higher and many, statistically significant.

The long-term changes in the SST database are generally toward warmer annual temperatures. This trend reflects elevations in summer as well as winter temperatures, and the changes are site-specific. This suggests that different reef sites are under the influence of different thermal stresses and that the ecological responses should be expected to differ accordingly. Some reefs have been stressed to a greater degree or more often than others. Flower Garden Bank and Salvador, Brazil represent unique cases in the Caribbean and juxta-Atlantic regions because they are the only sites with negative trends in mean temperature with time. More detailed examination of temperature records at these two sites show that in fact the mean maximum temperatures are rising with time, but these rises are more than compensated for by decreases in the mean minimum temperatures. Such increasing seasonal variance with time may be due to more severe winter cold spells and cold air masses from continental land masses.

A new awareness of regional surface currents is also reflected in the SST database. In addition to inflows from equatorial currents, the trans-Caribbean flow leading to the Yucatan current, the Florida Straits current, and the Gulf Stream flow contain loop currents, and the flow into the Windward Islands off the open Atlantic shelf edge includes numerous eddies and gyres. Although net current flow in the basin is from east to west across the region, local surface currents most likely depend upon wind strength and direction. From our data, the Western Caribbean appears to be warming more rapidly than the Eastern Caribbean, including the entire Gulf Stream influx zone. This implies that there may be increased heat flow out of the Caribbean basin. It should be noted that the oceanographic current database has been inadequate to resolve changes in Gulf Stream heat flow (Bryden et al. 2005) that the satellite temperature data seem to show clearly.

SST records for coral reef sites within geographic quadrants of the Caribbean basin that were matched for similar latitudes or longitudes reveal differences between sub-regions. Viewing the four quadrants of the basin, comparative data become geographically significant and suggest changing patterns of water movement and heat transport within the region. Data from these sites suggest that modifications in local water flow and/or heat transfer patterns may be driven by climate change.

Our analysis of SST data from the GCRA database also suggests that sub-regional flow in different areas of the basin may vary. Using SST trends over time as an indicator for water mixing, current flow may have been altered during the recent two decades of active climate change. Other variables may accompany these changes, such as wind velocity and direction.

Mass coral reef bleaching has been the most widely studied stress response of reefbuilding corals. Several environmental factors have been implicated in the phenomenon, but elevated temperature appears to be the triggering environmental condition. One of the earliest suggestions that mass coral reef bleaching and elevated temperature (global warming) might be causally linked emerged from observations that we reported over twenty-five years ago (Hayes \& Goreau 1991). A significant report on bleaching in the Galapagos islands of the Pacific also recognized this association, but attributed the temperature elevation to the El Niño phenomenon (Glynn 1983). Other factors, 
such as increases in ultraviolet penetration, light intensity, bacterial infections, chemical pollution, human population pressure, overfishing, and sediment loading contribute to the onset or severity of stress upon coral reefs, but these agents and activities merely exacerbate the negative impacts of preceding elevations in ambient temperature. The specific role of elevated sea surface temperature in reef stress was identified as the primary insult to coral reefs following an analysis of only seven Caribbean reef sites (Goreau et al. 1992). In that study, it was determined that satellite-derived SSTs tended to fall within $0.2^{\circ} \mathrm{C}$ of ground-truthed data and that a threshold SST of approximately $29.6^{\circ} \mathrm{C}$ was sufficient to account for coral reef bleaching in the Caribbean, although the threshold corresponded not to an absolute temperature but to a thermal anomaly of around $1^{\circ} \mathrm{C}$ over historical maximum monthly averages integrated over a one month period. Other studies have confirmed these results (Glynn 1993, Quinn \& Kojis 1994, Strong et al. 2000, McWilliams et al. 2005). That original study was later followed by a more extensive analysis that introduced the Hot Spot concept (Goreau \& Hayes 1994). These seminal analyses have now been expanded through more recent studies, lending strength to the observation that SST triggers ecological stress in coral reef communities (Goreau \& Hayes 2005a,b, Goreau, Hayes \& McAllister 2005).

By analyzing and comparing regional reef sites using the same satellite-derived database, a clearer picture of the regional influences of global warming on coral reefs is possible. From these data, we can begin to look carefully to identify SST trends and to correlate these changes with marine ecosystem responses. Access to the GCRA Coral Reef SST Database also may enable marine scientists and policy makers in developing nations to track events in their local reef communities, and may even provide the basis for meaningful intervention strategies derived from careful monitoring of changes in coastal water conditions.

The Caribbean region has experienced many significant local and regional changes in sea surface temperature over the past two decades. Those SST changes are documented in the GCRA Coral Reef SST Database for a 20-year period between 1984 and 2003. Warming of the coastal Caribbean Sea and adjacent North and South Atlantic Ocean has been progressively active during this time frame. Coastal marine ecosystem responses to stresses from global warming have been observed and reported extensively by marine scientists in the region. Coral reef bleaching, the uncoupling of the normal symbiotic relationship between dinoflagellate algae (zooxanthellae) and reef-building corals, has become nearly an annual event at some sites. Bleaching of reef organisms may contribute to severe ecosystem decline, loss of biodiversity, and significant physical degradation of coral reef ecosystems and reef-associated ecosystems (sea grass beds, mangroves and beaches). Significant reductions in greenhouse gas emissions will be required to limit future climate change.

From this analysis of the SST record, it is now evident that warming trends have occurred during both summer \& winter seasons. Furthermore, it is evident that this warming has stressed some coral reef tracts to a greater extent than others. The stress level upon the coral reef biota is a function of not only the intensity of heating, but also the duration of exposure to heat (Glynn 1993). Furthermore, we hypothesize from our SST data that alterations in ocean circulation patterns may be partly responsible for these observed fluctuations of sea surface temperature.

Our study reveals the circumstances under which average surface ocean warming is likely to result in sufficiently stressful thermal anomalies and perhaps contribute to other natural resource responses. These thermal conditions appear to be site-specific. Thus, all coral reefs would not be expected to be affected to the same degree or at the same time. As demonstrated through this analysis of Caribbean and Atlantic sites, the GCRA database of global SSTs provides both historical and interpretive data for understanding and predicting local and regional coral reef ecosystem responses to a rapidly changing climate system. 


\section{RESUMEN}

Una base de datos del promedio mensual de la temperatura de la superficie del mar (SST, por sus siglas en inglés: sea surface temperature) entre 1984 y 2003, ha sido desarrollada con los registros del Radiómetro Avanzado de Muy Alta Resolución (AVHRR: Advanced Very High Resolution Radiometer) del Satélite Operacional Polar Ambiental (POES: Polar Operational Environmental Satellite) de la Administración Atmosférica y Oceánica Nacional de los Estados Unidos (NOAA: National Oceanic and Atmospheric Administration). Estos registros corresponden a las coordinadas geográficas de 51 regiones arrecifales a lo largo del Mar Caribe y el Océano Atlántico. Estos datos son parte de los registros de SST de 206 sitios de arrecife de coral distribuidos por todo el mundo, de la Base de Datos de SST de Arrecifes de Coral (www.globalcoral. org) de la Alianza Mundial de Arrecifes de Coral (GCRA: Global Coral Reef Alliance). Las series de temperaturas cubren dos décadas de un activo cambio climático y de impacto en los ecosistemas marinos. Durante este período se reportaron blanqueamientos masivos de los arrecifes coralinos, el surgimiento de enfermedades, pérdidas en la biodiversidad, mortalidad de especies, un decaimiento en las pesquerías, y una degradación de las estructuras arrecifales. Los cambios en los arrecifes coralinos se producen cuando la anomalía de la SST mensual excede en $1.0^{\circ} \mathrm{C}$ el promedio de las épocas más cálidas, y se define como Punto Caliente (Hot Spot). Si la anomalía excede en $2^{\circ} \mathrm{C}$ o más y/o si la duración de la anomalía se prolonga en un mismo sitio, las respuestas ecológicas son más severas. Las líneas de tendencias y coeficientes de regresión de la SST de cada sitio documentan tanto el grado como la tasa del cambio en la temperatura, lo que permite comparaciones entre los sitios. Los impactos del afloramiento costero, el cual hace circular a la superficie aguas profundas, frías y ricas en nutrientes, $\mathrm{y}$ altera la productividad de las pesquerías del arrecife, también están presentes en el registro de la SST. Las temperaturas máximas y mínimas, las variaciones anuales en la SST, y las fluctuaciones estacionarias pueden ser analizadas con esta base de datos. Estos datos calibrados y comparables, sirven para describir hasta qué punto difieren o coinciden las tendencias de la SST entre sitios vecinos. Los registros de temperatura de un sitio específico ofrecen las bases para desarrollar estrategias individualizadas de manejo y para formular políticas de conservación únicas para los arrecifes regionales. Las diferencias entre las tendencias de temperatura podrían corresponder con la degradación de algunos arrecifes y el poco impacto relativo en otros. Partiendo de este registro histórico de las condiciones térmicas de los arrecifes coralinos, podemos generar alertas sobre potenciales respuestas de los ecosistemas marinos al persistente cambio climático.

Palabras clave: temperatura de la superficie del mar, blanqueamiento de coral, Caribe/Atlántico.

\section{REFERENCES}

Alley, R., et al. 2007. Climate change 2007: The physical science basis. Summary for policymakers. Intergovernmental Panel on Climate Change, Geneve, Switzerland.

Andreae, M.O., C. D. Jones \& P.M. Cox. 2005. Strong present-day aerosol cooling implies a hot future. Nature 435: 1187-1190.

Barnett, T.P., D.W. Pierce, K.M. AchutaRao, P.J. Gleckler, B.D. Santer, J.M. Gregory \& W.M. Washington. 2005. Penetration of human-induced warming into the world's oceans. Science 309: 284-287.

Boyer, T.P., S. Levitus, J.I. Antonov, R.A. Locarnini \& H.E. Garcia. 2005. Linear trends in salinity for the World Ocean, 1955-1998. Geophys. Res. Lett. 32: L01604, doi:10.1029/2004GL021791.

Bryden, H.L., H.R. Longworth \& S.A. Cunningham. 2005. Slowing of the Atlantic meridional overturning circulation at $25^{\circ} \mathrm{N}$. Nature 438: 655-657.

Caldeira, K. \& M.E. Wickett. 2003. Anthropogenic carbon and ocean pH. Nature 425: 365.

Caldeira, K. \& M.E. Wickett. 2005. Ocean model predictions of chemistry changes from carbon dioxide emissions to the atmosphere and ocean. J. Geophys. Res. 11: C09S04, doi: 10.1029/2004JC002671.

Climate Diagnostics Bulletin, National Oceanic and Atmospheric Administration (NOAA), 1982-2003.

Curry, R., B. Dickson \& I. Yashahaev. 2003. A change in the freshwater balance of the Atlantic Ocean over the past four decades. Nature 426: 826-829.

Emanuel, K.A. 1987. The dependence of hurricane intensity on climate. Nature 326: 483-485.

Emanuel, K.A. 2005. Increasing destructiveness of tropical cyclones over the past 30 years. Nature 436: 686-688.

Glynn, P.W. 1983. Extensive 'bleaching' and death of reef corals on the Pacific coast of Panama. Environ. Conserv. 10: 149-153.

Glynn, P.W. 1993. Coral reef bleaching: ecological perspectives. Coral Reefs 12: 1-17.

Goreau, T.J., \& R.L. Hayes. 1994. Coral bleaching and ocean "hot spots". Ambio 23: 176-180. 
Goreau, T.J., R.L. Hayes, J.W. Clark, D.J. Basta \& C.N. Robertson. 1992. Elevated satellite sea surface temperatures correlate with Caribbean coral reef bleaching, p. 225-255. In R.A. Geyer (ed.), A Global Warming Forum: Scientific, Economic and Legal Overview. CRC, Boca Raton, Florida, USA.

Goreau, T.J. \& R.L. Hayes. 1995. Coral reef bleaching in the south central Pacific during 1994. Report to the International Coral Reef Initiative, U.S. Department of State. Washington, DC, pp. 1-201.

Goreau, T. J. \& R.L. Hayes. 2005a. Global coral reef bleaching and sea surface temperature trends from satellite-derived Hotspot analysis. World Res. Rev. 17: 254-270.

Goreau, T.J. \& R.L. Hayes. 2005b. Monitoring and calibrating sea surface temperature anomalies with satellite and in-situ data to study effects of weather extremes and climate changes on coral reefs. World Res. Rev. 17: 271-281.

Goreau, T.J., R.L. Hayes \& D. McAllister. 2005. Regional patterns of sea surface temperature rise: implications for global ocean circulation change and the future of coral reefs and fisheries. World Res. Rev. 17: 350-374.

Hansen, J., L. Nazarenko, R. Ruedy, Mki. Sato, J. Willis, A. Del Genio, D. Koch, A. Lacis, K. Lo, S. Menon, T. Novakov, Ju. Perlwitz, G. Russell, G.A. Schmidt \& N. Tausnev. 2005. Earth's energy imbalance: confirmation and implications. Science 308:1431-1434.

Hayes, R.L. \& T.G. Goreau. 1991. The tropical coral reef ecosystem as a harbinger of global warming. World Res. Rev. 3: 306-322.

Levitus, S., J. Antonov \& T. Boyer. 2005. Warming of the world ocean: 1955-2003. Geophys. Res. Let. 32: L02604, doi:10.1029/2004GL021592

McWilliams, J.P., I.M. Cote, J.A. Gill, W.J. Sutherland \& A.R. Watkinson. 2005. Accelerating impacts of tem- perature-induced coral bleaching in the Caribbean. Ecology 86: 2055-2060.

Parmesan, C. \& G. Yohe. 2003. A globally coherent fingerprint of climate change impacts across natural systems. Nature 421: 37-42.

Quinn, N.P. \& B.L. Kojis. 1994. Monitoring sea water temperatures adjacent to shallow benthic communities in the Caribbean Sea: a comparison of AVHRR satellite records and in situ subsurface observations. Mar. Tech. Soc. J. 28: 210-218.

Reynolds, R.W. 1988. A real-time global sea surface temperature analysis. J. Climate 1: 75-86.

Reynolds, R.W. \& D.C. Marisco. 1993. An improved real-time global sea surface temperature analysis. J. Climate 6: 114-119.

Reynolds, R.W. \& T. Smith. 1994. Improved global sea surface temperature analysis using optimum interpolation. J. Climate 7: 929-948.

Reynolds, R.W., N.A. Rayner, T.M. Smith, D.C. Stokes \& W. Wang. 2002. An improved in situ and satellite analysis for climate. J. Climate 15: 1609-1625.

Soden, B.J. 2000. The sensitivity of the tropical hydrological cycle to ENSO. J. Climate 13: 538-549.

Strong, A.E., E.J. Kearns \& K.K. Gjovig. 2000. Sea surface temperature signals from satellites - an update. Geophys. Res. Lett. 27: 1667-1670.

Webster, P. J., G. J. Holland, J. A. Curry \& H.-R. Chan. 2005. Changes in tropical cyclone number, duration, and intensity in a warming environment. Science 309: 1844-1846.

\section{INTERNET REFERENCES}

Global Coral Reef Alliance. 2005. GCRA Global Coral Reef Sea Surface Temperature Database: <http:// www.globalcoral.org>. 